Iwona Krycka-Michnowska

DOI $10.15290 / \mathrm{sw} .2016 .16 .04$

Uniwersytet Warszawski

Wydział Lingwistyki Stosowanej

Katedra Studiów Interkulturowych Europy Środkowo-Wschodniej

tel.: +48225534223

e-mail: iekrycka@uw.edu.pl

\title{
Zinaida Gippius o Kościele i chrześcijaństwie
}

Słowa kluczowe: nowy Kościół, chrześcijaństwo, odrodzenie, dziennik

Podążając za myślą Ottona Weiningera, Władisław Chodasiewicz utrzymywał, że Zinaida Gippius (1869-1945) - poetka i prozaik, publicystka, eseistka i autorka dzienników oraz wspomnień - ma naturę po kobiecemu uległą i naśladowczą, zaś jej opinie i sądy stanowią jedynie pochodną poglądów jej męża Dmitrija Mierieżkowskiego [Ходасевич 2008, 638-639]. Wbrew tej opinii liczne ego-dokumenty współczesnych pisarki dowodzą, że była ona nie tylko pierwszą czytelniczką, krytykiem oraz korektorką prac autora Chrystusa $i$ Antychrysta, ale też pomysłodawczynią wielu przedsięwzięć oraz idei, które następnie Mierieżkowski rozwijał i opracowywał [Белый 1990, 475, Злобин 1970, 20-21, Волкогонова]. Tezę tę potwierdza diarystyka Gippius, która wskazuje ponadto, że wraz z mężem pisarka była jedną z inicjatorek renesansu religijnego w Rosji na przełomie XIX i XX wieku.

Dążąc do ożywienia rosyjskiego życia religijnego, Mierieżkowscy stali się prekursorami „nowego chrześcijaństwa”. Rozczarowani prawosławiem propagowali doktrynę „nowej świadomości religijnej” ${ }^{1}$, której centrum sta-

1 Termin ten jest zazwyczaj używany w znaczeniu szerszym na oznaczenie religijnego ruchu modernistycznego w Rosji na przełomie wieków oraz węższym - na określenie doktryny stworzonej przez Mierieżkowskiego [Воронцова 2010, 51-61]. 
nowiła idea o mistycznej jedności i jednakowej wartości ducha i ciała, oraz podjęli działania zmierzające do realizacji marzenia o „Kościele prawdziwie powszechnym" [Мережковский 2000, 208-209]. Wraz z krytykiem i publicystą Dmitrijem Fiłosofowem zawiązali tajne kółko, które miało w praktyce ucieleśnić ideę „nowego Kościoła”, stać się jego zalążkiem i pierwowzorem społeczeństwa przyszłości. Ów „domowy” czy też, jak pisała Gippius, „wewnętrzny” Kościół „bez papieża i cezara” [Pachmuss 1972, 170] miał być przeciwwagą dla zinstytucjonalizowanych „Kościołów historycznych” oraz zalążkiem Kościoła niezależnego od państwa, opartego na równości, miłości chrześcijańskiej i wolności osobistej. Cenną inicjatywą Mierieżkowskich, która wpisała się w ducha renesansu religijnego w Rosji, była także organizacja Spotkań Religijno-Filozoficznych (1901-1903) w Petersburgu².

W odróżnieniu od racjonalistycznych teorii postępu społecznego, podobnie jak Władimir Sołowjow, Mierieżkowscy stworzyli koncepcję religijnego uzasadnienia biegu dziejów: historię interpretowali jako następstwo kolejnych epok religijnych, nieustanną wędrówkę ludzkości ku Bogu, proces doskonalenia się, prowadzący w ostatniej fazie do absolutnej wolności duchowej [Гиппиус 2002, 434]. Odwoływali się do poglądów chiliastów, zwłaszcza zaś do eschatologii historii średniowiecznego kalabryjskiego cystersa Joachima z Fiore. Za autorem Ewangelii wieczystej wyróżniali trzy wielkie etapy w historii ludzkości, inspirowane i zdominowane kolejno przez jedną osobę Trójcy Świętej: sytuujące się w przeszłości Królestwo Boga Ojca (Królestwo Starego Przymierza), istniejące współcześnie Królestwo Syna Bożego (Nowego Przymierza) oraz Królestwo Ducha Świętego (Królestwo Trzeciego Przymierza), które stanie się udziałem przyszłej ludzkości.

Jak zauważa Andrzej Walicki, idea stadiów objawienia w różnych wariantach była obecna także w myśli Friedricha Schellinga, mesjanistów polskich czy też romantycznych socjalistów francuskich. Tak więc Mierieżkowscy mogli czerpać inspirację również z tych źródeł [Walicki 2005, 735]. Szczególną wagę przypisywali spodziewanemu objawieniu Ducha Świętego, ucieleśnionemu, ich zdaniem, w Bogurodzicy-Dziewicy. Sądzili, że Bogurodzica, kojarzona przez nich z Wieczną Kobiecością, Wieczną Kobietą-Matką, Matką Niebieską i Sofią stanowi dopełnienie Trójcy Świętej, jest przejawem Świętego Ducha i Świętego Ciała zarazem. Oczekiwali nowej doskonałej epoki, w której zostanie pokonana śmierć, i która, dopełniając chrześcijaństwo,

\footnotetext{
2 Projekty te opisała Zinaida Gippius w dziennikach O Быєвшем (1899-1914) (O Tym, co byto (1899-1914)), Contes d'amour. Dzienniku historii mitosnych (1893-1904), w zapiskach Парижская ажанда (Terminarz paryski), we wspomnieniach Дмитрий Мережковский (Dmitrij Mierieżkowski), w swej korespondencji oraz eseistyce.
} 
odsłoni tajemnicę płci oraz zniweluje wszelkie antynomie ${ }^{3}$. Mierieżkowski głosił:

Первый Завет, откровение Отца, - тезис; Второй Завет, откровение Сына, - антитезис; совершенный синтез Первого и Второго Завета в Третьем, последнее соединение Отца и Сына в Духе не могло произойти прежде, чем не раскрылась совершенная противоположность Отчей и Сыновней ипостаси. Кажущиеся неразрешимыми противоречия христианства - вечные антиномии плоти и духа, земли и неба, мира и Бога - суть в действительности не противоречия неразрешимые, а только противоположности неразрешённые, но разрешаемые в последнем соединении Двух во Едином, в последнем откровении Троицы [Мережковский 1914, 154].

Po opuszczeniu Rosji wskutek przewrotu bolszewickiego Zinaida Gippius i Dmitrij Mierieżkowski propagowali swe poglądy religijno-filozoficzne, głównie koncepcję chrześcijaństwa apokaliptycznego na emigracji. Mimo fiaska działalności religijnej, czego wyrazem był rozpad trójbraterstwa założonego wspólnie z Fiłosofowem na przełomie wieków, pisarka nie odżegnała się od przeszłości i istoty swych poszukiwań. Starając się urzeczywistnić swe ideały, już na początku lat dwudziestych zainicjowała powstanie stowarzyszenia religijnego a zarazem politycznego - Sojuszu Nieprzejednanych. Głównym celem, jaki stawiali przed sobą odrzucający bolszewizm, materializm i ateizm członkowie Sojuszu, miało być uduchowienie, przebóstwienie świata i ludzkości na fundamencie braterstwa, wolności, równości, miłości chrześcijańskiej, a także wzajemnego szacunku i ofiarności. Owi „poszukiwacze światła" starali się kontynuować zapoczątkowaną na przełomie wieków utopijną misję urzeczywistnienia Królestwa Bożego na ziemi. Pierwszym krokiem ku temu miały być wspólnoty Ducha, związki i stowarzyszenia w rodzaju Sojuszu Nieprzejednanych, które w przyszłości winny się zjednoczyć w „Bogoludzkość” [Гиппиус 1990, 218].

Podsumowaniem i wykładnią rozbudowywanego przez kilka dziesięcioleci systemu religijno-filozoficznego Zinaidy Gippius jest dziennik Bъъбор? (1929-1930) (Wybór?), który stanie się głównym przedmiotem rozważań. Dziennik ten uogólnia przemyślenia pisarki w sferze teologii, odsłania jej spojrzenie na Chrystusa i chrześcijaństwo oraz Kościół i Królestwo Boże na ziemi. Tradycyjna egzegeza biblijna, interpretacja fragmentów Nowego Testamentu oraz nauczania Ojców Kościoła i mistyków chrześcijańskich konfrontowana jest tu z doświadczeniem czy też objawieniem wewnętrznym, myślami epifanicznymi autorki.

3 Więcej na ten temat zob. Krycka-Michnowska [2013, 37-50] oraz Krycka-Michnowska [2014, 9-19]. 
Przedmiotem dyskursu w dzienniku, którego forma zbliża go do eseju filozoficzno-religijnego, są fundamentalne pojęcia chrześcijańskiej teologii, eschatologii i soteriologii: cierpienie, zbawienie, odkupienie, wieczność, zmartwychwstanie, wolna wola. Zarówno twierdzenia o charakterze aksjomatów, jak i własne intuicje oraz oparte na nich teorie diarystka ujmuje w formie hipotez, nie starając się ich zdogmatyzować. Rozpoczyna dziennik wyjaśnieniem swej metody dochodzenia do prawdy:

Это всего только логическая схема. Вероятность, предположение, что оно так. Исключать возможность, что оно так, обойти эту мысль, или взять её поверхностно, не до дна и конца - невозможно. Я, по крайней мере, не могу. Да и никто, если понять её действительно изнутри [Гиппиус 2005, 148].

Ów „schemat logiczny” buduje za pomocą zdań warunkowych i trybu przypuszczającego, używa spójników „jeśli” lub „gdyby” oraz przysłówków „prawdopodobnie” bądź „przypuszczalnie”. Na hipotetyczny charakter przedstawianych wywodów wskazuje również zawarty w tytule znak zapytania. Tym samym pisarka wskazuje na niepewność przytaczanych przez siebie powszechnie przyjmowanych twierdzeń oraz warunkowość czy też życzeniowość własnych domysłów i przypuszczeń; sugeruje, że nie są one oczywiste, lecz jedynie możliwe.

Zasadniczo w dzienniku wyróżnić można dwie główne części: w pierwszej autorka prezentuje nauczanie Kościołów chrześcijańskich dotyczące zbawienia i prowadzącej do niego drogi, w drugiej - wyraża własne stanowisko religijne. Szczególna rola przypada sporządzanym podczas kolejnych odczytań tekstu uwagom na marginesach, stanowiącym komentarze do jego poszczególnych części. Diarystka prowadzi dialog sama ze sobą i ewentualnymi oponentami. W komentarzach z perspektywy czasu rozmaicie ocenia to, co napisała. Dążąc do obiektywizmu, wysuwa zastrzeżenia, stawia znaki zapytania, przyznaje się do niepewności i niewiedzy. Zastanawia się, czy jej sprzeciw wobec tego, w co wygodniej i łatwiej byłoby wierzyć, nie jest jedynie odwiecznym nierozumnym buntem przeciwko Prawdzie:

От „не хочу” я не отрекаюсь. Но, ради полнейшей объективности, укажем, что ещё такое может быть возражение: „не хочу” - ничего не стоит в устах всякого, кто опытно не знает полноты того, что даётся „взамен”, кто не нашёл, не увидел „жемчужины”, ради которой всё остальное сделалось ему действительным néant. Самое вот это „не хочу”, [...] - только доказательство слепоты, неведения и недостаточного пленения.

Испытай, тогда посмотрим, скажешь ли „не хочу”.

Может быть, и не скажу Наверно не скажу. Я, другой, третий, каждый пленённый [...]. Но это ничего не меняет, ничего! До такой степени не меняет, что я, может быть, и пленяться не хочу, если оно так. Всякому 
„хочется” вырваться из „проклятого” места, самому-одному. Но „не хочу” больше, глубже, первее, важнее, человечнее „хочется-не хочется” [Гиппиyc 2005, 166].

Autorka rozwija swe koncepcje w dialogu z myślą i tradycją chrześcijańską. Wielokrotnie odwołuje się do Biblii, która stanowi główny punkt odniesienia dla jej rozważań. Często cytuje a następnie interpretuje jej fragmenty, zwłaszcza - przypowieści Jezusa i Kazanie na Górze, przywołuje biblijne obrazy i postacie. Przytacza słowa mistyczki katolickiej św. Teresy z Avila.

Początkowo Gippius sporządzała notatki „dla nikogo”, czyli dla siebie, próbując skonfrontować wszystkie „za” i „przeciw” drogi do Boga, którą obrała; dziennik był wyrazem jej dążenia do usystematyzowania własnej koncepcji religijno-metafizycznej. Z biegiem czasu zapragnęła, aby z zapiskami zapoznali się jej najbliżsi, rozważała też możliwość ich poprawienia i publikacji. Oprócz dominującej w dziennikach duchowych czy też religijno-filozoficznych postawy wyznania w notatkach diarystycznych rosyjskiej pisarki dopatrzyć się można postawy wyzwania [Czermińska 2000, 19-52]. Autorka, która manifestowała tam poglądy w wielu kwestiach odmienne od powszechnie przyjętych, rzucała światu wyzwanie w formie osobistego „nie chcę".

Punktem wyjścia refleksji Zinaidy Gippius jest dualizm metafizyczny oraz antropologia chrześcijańska. Pisarka zakłada współistnienie dwóch przeciwstawnych, a zarazem dopełniających się, nierozłącznych bytów, które nawzajem się przenikają, stanowiąc całość: to z jednej strony ograniczone ramami przestrzenno-czasowymi „tu” i „teraz”, z drugiej - wyższa realność, „tam”. Jednocześnie jest przekonana, że stworzony „na obraz i podobieństwo" Boga człowiek jako istota duchowo-cielesna ma przeczucie istnienia innej, niepoznawalnej realności. Nosi w sobie jej zalążek, co umożliwia mu komunikację z transcendencją, spotkanie z Absolutem. Doznaje odmienności a zarazem mistycznej jedności bytów, co jest przyczyną jego tragedii.

Diarystka czerpie inspirację z myśli Henriego Bergsona o czasie rzeczywistym, czasie abstrakcyjnym i przestrzeni [Skarga 1982, 30-56]. Podobnie jak ten filozof zakłada, że przeszłość (i przyszłość) trwa, a więc jest obecnością. Zwraca uwagę na ograniczone zdolności poznawcze człowieka, który może myśleć tylko w kategoriach przestrzennych. W taki zniekształcony sposób intelekt ujmuje zanurzony w trwaniu świat, który nieustannie się przekształca. Idąc tropem francuskiego myśliciela, Gippius abstrahuje od fizykalnego wyobrażenia czasu i przestrzeni na rzecz ich metafizycznego ujęcia; wiąże w ten sposób ziemską i pozaziemską realność: 
„та реальность” не может быть втянута в эту, ибо она уже в этой, но наши глаза должны открыться (или сердце, или вся наша внутренность) на их неразделимость и неслиянность во всём. И это откроет Утешитель [Гиппиус 2005, 158].

Doświadczenie mistyków chrześcijańskich: świętej Teresy od Jezusa, św. Jana od Krzyża czy też św. Serafina z Sarowa pozwala pisarce wierzyć, że „teraz” i „potem”, „przed” i „po” śmierci nie istnieje; „tamten świat” może być również „tu”, na ziemi. Przede wszystkim jednak Zinaida Gippius przywołuje postać Chrystusa, który, zmartwychwstając, „rozerwał zasłonę nad tajemnicą" łączącą obydwa byty. Powołując się na mistyków katolickich i prawosławnych, pisarka prowadzi ekumeniczny dialog. Poszukuje wspólnego mianownika czy też uniwersalnych punktów odniesienia dla duchowości Wschodu i Zachodu. Taka postawa była zgodna z atmosferą okresu porewolucyjnego, gdy na emigracji znalazło się wielu wybitnych rosyjskich teologów i filozofów.

Głównym tematem dziennika jest zbawienie. Zinaida Gippius analizuje wskazaną przez Jezusa drogę do zbawienia prowadzącą poprzez cierpienie. Próbując dociec jego istoty, posługuje się metaforycznym językiem. Cierpienie porównuje do nieruchomej, niedającej się rozbić czary, w której wrze świat. Dzieje ludzkości natomiast interpretuje jako rozciągniętą w czasie, nieustanną, lecz bezskuteczną walkę z nim. Przytacza świadectwa świętych, którzy przekonywali, że pogłębia ono miłość do Chrystusa. Zwraca uwagę na wyjątkową rolę chrześcijaństwa w przewartościowaniu stosunku do cierpienia jako doświadczenia pozytywnego oraz podejmuje propagowaną przez nie myśl o konieczności przyjęcia krzyża w imię miłości do Zbawiciela, który jest „drogą i prawdą, i życiem” [Ewangelia wedlug św. Jana 14, 6]. Odtąd sposobem na przezwyciężenie cierpienia stało się dobrowolne przyjęcie go: człowiek nie powinien walczyć z cierpieniem bądź przed nim uciekać, lecz wyjść mu naprzeciw, przeniknąć w jego głębię:

надо повернуться лицом к страданию [...]. А повернувшись - двинуться к нему; а подойдя - прикоснуться к нему; а прикоснувшись - проникнуть в него, в самую глубь или толщу, чтобы пройти, сквозь и через, туда, где находится победное оружие [Гиппиус 2005, 152-153].

Sięgając istoty chrześcijaństwa, diarystka przypomina, że Chrystus otworzył drogę do zbawienia i wiecznego zmartwychwstania tym, którzy zechcą uwierzyć w Niego, pokochać Go i przyjąć cierpienie. Podkreśla zarazem, że stworzony na podobieństwo Boga człowiek jest także obrazem Bożej wolności, posiada zatem nieograniczoną możliwość wyboru: może przyjąć lub odrzucić wolę Stwórcy. Obdarzony wolną wolą - może dokonywać 
wyborów, ale wybór, który proponuje chrześcijaństwo, jest, jak twierdzi Gippius, pozorny. Polegać ma bowiem na odwróceniu się od świata, wyklęciu go i osądzeniu, co narusza tajemną więź między dwoma bytami realnym i idealnym. Budzi to sprzeciw pisarki; przede wszystkim jednak autorka zapisków nie chce pogodzić się z myślą o zbawieniu jedynie dla wybranych. Wyraża przekonanie, że Chrystus, czyli doskonała, nieskończona Miłość, swym cierpieniem odkupił cały świat. Upomina się zwłaszcza o tych, którzy nie mogą usłyszeć wołania Boga bądź nie umieją dokonać właściwego wyboru:

но вот с чем не мирится лучшая часть человеческого существа: пусть каждому, „имеющему уши, чтобы слышать”, и очи, чтобы видеть, открыт путь спасения от страданий, путь самый верный, самый необманный; и пускай даже каждый из этих каждых, если не захочет выбрать путь, не „обратится” (лицом к страданию) - погибнет бессмысленно и страшно под упавшей на него башней; но разве „мир” и есть лишь сумма этих „каждых”? А другие? Другие и всё другое, кто и что не могут, наверно, совсем и никак, услышать зова, вообще никак сделать выбора, до такой степени, - что этот выбор им как бы даже и не предлагается? Это „всё” (живое), наполняющее и составляющее „мир сей”, - с ним вместе отставляется; оно-то и обрекается на уже безысходные (проклятые) страдания. Этого „иного” обречённого куда больше, чем всех „каждых”; - дети, да вся „тварь стенающая"... нет, она „каждыми” не спасается [...].

„Билет” Достоевского - это и есть отречение одного из „каждых” от своих преимуществ, если „спасутся только некоторые” (каждые). [...]

в этом уже всё; уже ясно, почему я не хочу верить, что именно этот Христос указывал нам именно на этот путь; чтобы Истина и Путь (Христос) были именно таковы [1929, 161-162].

Przejawia się tu maksymalizm i skrajny idealizm pisarki. Jej postawa wyraża indywidualistyczny bunt, niemniej u jego podłoża - jak przekonuje leży ogólnoludzkie „nie chcę”. Odwołując się do autorytetu Fiodora Dostojewskiego, diarystka przypomina postać indywidualisty i krytyka chrześcijaństwa Iwana Karamazowa, który podejmuje decyzję o „zwróceniu biletu” do harmonii, jeśli ta miałaby być osiągnięta za cenę łzy chociażby jednego niewinnego dziecka [Dostojewski 2004, 333-314]. Podobnie jak bohater Dostojewskiego nie chce wizji raju, do którego inni mieliby nie uzyskać dostępu. Nawiązuje także do idei apokatastazy, nauczania o zbawieniu powszechnym. Nadzieja powszechnego zbawienia, charakterystyczna dla myśli wschodniej, była obecna w refleksji teologów i filozofów rosyjskich, takich jak: Nikołaj Bierdiajew, Siergiej Bułgakow [Bułgakow 1992, 197-201] czy Nikołaj Łosski. Także Paweł Jewdokimow dowodził, że prawosławne teksty liturgiczne kierują nadzieję wierzących ku bezgranicznemu miłosierdziu Bożemu. Nie 
jest to jednak pewność doktrynalna, ale wiara w możliwość jej zaistnienia [Evdokimov 1964, 362-373], [Evdokimov 1979, 70-72].

Zinaida Gippius nie godzi się również na cierpienie ludzkości. Nie chce, by po Odkupieniu, zbawczym dziele Jezusa Chrystusa, ktokolwiek cierpiał. Wybiera raczej własne cierpienie niż cierpienie innego człowieka, zwłaszcza tego, kogo kocha:

да, я не хочу, чтоб за меня кто-нибудь страдал, а любимый - совсем не хочу, не могу вытерпеть. Чем совершеннее любовь - тем это невыносимее. Уже лучше самому страдать за. Отсюда, из глубин этого „лучше”, является, [...] страсть к страданию, подобному Христову (и больше, если можно) у святых, с их великой любовью ко Христу. Страсть ко кресту. [...] Да, „лучше” самому страдать за, и это просто говорит Любовь [...]. Тем невыносимее, чем больше любишь Христа [...], смотреть на Его Страдание, да ещё знать, что оно было (значит, и есть) за тебя [Гиппиус 2005, 163-164].

Pisarka powraca do kwestii cierpienia również kilka lat później w korespondencji ze swą przyjaciółką Gretą Gerell, dowodząc, że podobnie jak śmierć i grzech pochodzi ono nie od Boga, który jest Miłością i Wolnością, lecz od Jego wroga. Po raz kolejny nawiązując do myśli Dostojewskiego wyrażonej w legendzie o Wielkim Inkwizytorze, łączy kategorię cierpienia z kategorią wolności. Przekonuje, że słaby człowiek nie jest jeszcze w stanie unieść wolności, która jest darem, a zarazem brzemieniem:

Бог допускает страдание не потому, что Он желает перехода человека от Дьявола к Богу через своё страдание. Бог не пользуется этим средством; нет, потому что Он - Бог Свободы. Он любит свои создания; хочет, чтобы они были во всем свободны; их страдание печалит Его; даже больше - Он страдает с нами. Он жалеет нас, но никогда не переделывает того, что было Им уже создано; [...] Бог создал человека свободным, но человек не заслужил ещё этой свободы.

Страдание и смерть не от Бога, и человек должен бороться против них [Пахмусс 2002, 213].

W dzienniku Wybór? Zinaida Gippius konfrontuje ortodoksyjną wykładnię chrześcijaństwa z jego modernistyczną koncepcją. Podobnie jak Dmitrij Mierieżkowski, moderniści katoliccy czy wcześniej John H. Newman, opowiada się za ewolucjonistyczną koncepcją dogmatyki chrześcijańskiej oraz ideą rozwoju doktryny wiary [Dessain 1989]. Wysuwa przypuszczenie, że formuły teologiczne nie odzwierciedlają w sposób idealny rzeczywistości Bożej, lecz ukazują jej rozumienie zgodne z terminologią danej epoki. Stąd, jej zdaniem, potrzeba ożywienia doktryny, która powinna reago- 
wać na problemy współczesnego świata, próbować odsłaniać to, co w pełni zostanie odkryte dopiero $\mathrm{w}$ przyszłości.

Pisarka podkreśla wyjątkową rolę wszystkich Kościołów chrześcijańskich w głoszeniu testamentu Chrystusa: wskazywaniu jednego obrazu Odkupiciela oraz jedynej drogi do zbawienia. Jednak Kościoły te ujmuje wyłącznie jako chrześcijaństwo osoby. Już w 1906 r. w artykule Без мира (Веz świata) głosi:

христианства общего, общественного, всечеловеческого, церковного в высшем смысле, - не было, не могло и не может быть, потому что христианство не иерковно [...]. Я не знаю, я не могу постичь, что отнимет у христианина, то есть у человека с личной, искренней верой во Христа [...] признание, что „христианство” и есть именно полная, личная вера в одну Божественную Личность? Если мы скажем, что Христос открыл нам только эту необходимейшую „правду о личности”, „правду о человеке”, которая не есть ещё соединение отдельных людей, познающих лишь себя и Единого, в одно новое тело, если мы скажем, что Христос только Путь к такому соединению всех, - умалит ли это Христа? Христианство не церковно, но оно - путь к церкви, путь самоуглубления в одинокой ещё, личной вере, - и этому пути человеческая история не изменила [Гиппиус 2003, 147].

Przekonuje, że odsłaniają one przed każdym człowiekiem pełnię prawdy o osobie, o ,,jednym”, proponując każdemu indywidualne zbawienie i jedną drogę do niego - przez Kościół. Sądzi, że „historyczne chrześcijaństwo” nastawione jest na samodoskonalenie, wzrastanie indywidualne, dążenie do osobistej świętości, zaś w liturgii „dla wielu” samotnych, nic niewiedzących o sobie nawzajem osób, gubi się aspekt wspólnotowy - istota agapy [Pachmuss 1972, 493].

Nawiązując do myśli sformułowanej przez Mierieżkowskich już na początku wieku, pisarka stawia hipotezę, że „Kościoły historyczne” nie umożliwiajac zbawienia całemu światu; ma to wynikać z faktu, że nie odsłoniły one idei prawdziwej jedności, „soborowości”, nie potrafiły stworzyć autentycznej braterskiej wspólnoty, komunii ludzi, lecz jedynie o nich mówią. Opisywana sytuacja ma być skutkiem tego, iż nie odkryły one przekazanego przez Chrystusa skarbu - ujętej w formie dogmatu prawdy o „Troistości Boga”, świata i człowieka. Wielka misja odsłonięcia tajemnicy Świętej Trójcy leży przed apokaliptycznym Kościołem przyszłości [Pachmuss 1972, 170]. Zdaniem pisarki „Kościoły historyczne” koncentrują się na głoszeniu nauki Chrystusa, zaś jedynie w obrzędach wspominają o Bogu Ojcu i Duchu Świętym. Z drugiej strony indywidualną wiarę w Jezusa uznaje za niezbędny warunek powszechnej wiary w Boga Ojca i Ducha Świętego. 
Jak niegdyś Zinaida Gippius wyraża tęsknotę za „Kościołem powszechnym" ujmowanym jako doskonała, zintegrowana wiarą w Boga i wzajemną miłością wspólnota ludzi; Jednia, która pogodzi postawę indywidualistyczną i kolektywizm oraz da poczucie ciągłości jednostki z ludzkością. Analizując doktrynę chrześcijańską, dopuszcza możliwość omyłki, sugeruje, że w ciągu wieków nauczanie Chrystusa mogło być nieprawidłowo interpretowane, zaś Ewangelie - „nieodczytane/niedoczytane”. Podobnie jak powołujący się na apokryfy Dmitrij Mierieżkowski, wysuwa hipotezę, że ludzkość ciągle jeszcze nie poznała Jezusa, a „chrześcijaństwo historyczne” nie odkryło Jego prawdziwego oblicza (bądź też odsłoniło tylko część prawdy o Nim) [Meрежковский, 1932]:

Воскресение Спасителя - победа над страданием, которому он пошёл навстречу, над смертью, - а что, если это мы опять, по невозможности понимать что-либо иначе, - поместили его во времени? Что, если воскресение - истина, но прикоснуться к ней, воспринять её мы-то можем - только в подобии? [...].

Замыкается круг, полнота победы над страданием и смертью, - это и есть вечное воскресение. Не „момент” (время кончилось), а вечность [Гиппиус 2005, 156].

Konfrontując własne intuicje dotyczące istoty Boga z tradycją chrześcijańską, jak już była mowa, pisarka nie stara się formułować aksjomatów, dopuszcza możliwość własnej pomyłki, ale też - niepełną interpretację nauczania Jezusa przez „historyczne chrześcijaństwo”. Prawdopodobnie odwołując się do nauki hezychastów dowodzących, że choć istota Boga jest niepoznawalna, to Bóg przejawia się w swych energiach, m.in. w światłości, diarystka sugeruje, iż jej blask mógł oślepić ludzkość, jak niegdyś oślepił Szawła.

Zinaida Gippius wierzyła w rozwój Kościoła, w to, że zgodnie z duchem czasów będzie on odsłaniał prawdy zawarte w dogmatach, a zarazem przeciwstawiała się zinstytucjonalizowanemu chrześcijaństwu kościelnemu. Opowiadała się za prawem każdego człowieka do wolności wyboru. Broniła własnej drogi religijnej, którą nazwała drogą „od Chrystusa przez chrześcijaństwo do Kościoła" [Pachmuss 1972, 483]. Miała nadzieję, że jej intuicje teologiczne w przyszłości zostaną potwierdzone.

Analiza dziennika Wybór? systematyzującego poglądy religijno-filozoficzne Zinaidy Gippius, pokazuje, że jego autorka niemal do końca życia pozostała wierna marzeniom o wielkiej odnowie chrześcijaństwa oraz własnej w nim misji, zwłaszcza zaś - koncepcji ,jednego, nowego Kościoła powszechnego". Głosiła potrzebę stworzenia autentycznej wspólnoty, sojuszu 
serc i umysłów wszystkich wierzących, konieczność ożywienia wiary i wyeksponowania w niej znaczenia Hipostazy Ducha Świętego, przysłoniętego, jak mniemała, kultem Chrystusa. Propagowała ideę trynitarności, potrzebę przeniknięcia w tajemnicę Trójcy Świętej i doświadczalnego uwidocznienia więzi Syna z Ojcem i Duchem ujętej dotychczas w formie niedostępnego dogmatu. Wystąpiła jako krytyk „Kościołów historycznych” oraz propagatorka idei duchowego odrodzenia ludzkości.

W dochodzeniu do prawdy opowiedziała się za pluralizmem epistemologicznym. Nie kierowała się autorytetem bądź literą prawa, lecz rozumem oraz głosem wewnętrznym, intuicją, umożliwiającą, jak sądziła, uchwycenie istoty rzeczy i kontakt z Absolutem. Jej bazą etyczną stały się idee „nowej świadomości religijnej”, zmierzające do pogodzenia doświadczenia religijnego i zmysłowego (świętości ducha i ciała) oraz szczególne pojmowanie roli chrześcijaństwa w przebudowie struktury społecznej i politycznej. Zapiski poświęcone refleksji religijnej prezentują nie tylko odwagę poznawczą autorki, ale tė̇ wątpliwości i obawy - lęk przed pobłądzeniem i wyciągnięciem pochopnych wniosków, jak i przed zaniechaniem poszukiwania prawdy.

W postawie pisarki ujawnia się „swoisty anarchizm rosyjski na gruncie religijnym", jak to ujął Nikołaj Bierdiajew, mając, co prawda, na myśli samego siebie [Bierdiajew 2002, 231]. Niegdyś bliska Bierdiajewowi Zinaida Gippius, podobnie jak on, była modernistką religijną w chrześcijaństwie upatrującą religię wolności i twórczości, a nie autorytetu i tradycji.

\section{Literatura}

Bułgakow S., 1992, Prawostawie. Zarys nauki Kościoła prawostawnego, przeł. ks. H. Paprocki, Warszawa.

Czermińska M., 2000, Autobiograficzny trójkat. Świadectwo, wyznanie i wyzwanie, Kraków.

Dessain Ch.S., 1989, John Henry Newman: pionier odnowy Kościoła, przeł. M. Stebart, Poznań.

Dostojewski F., 2004, Bracia Karamazow, przeł. A. Wat, oprac. J. Smaga, t. 1 Wrocław - Warszawa - Kraków.

Evdokimov P., 1964, Prawostawie, przeł. ks. J. Klinger, Warszawa.

Evdokimov P., 1979, Od śmierci do życia, „Novum” nr 11, s. 60-74.

Ewangelia wedtug św. Jana 14, 6.

Krycka-Michnowska I., 2013, O „Świętej Wspólnocie”, rewolucji i Antychryście. Poszukiwania religijne inteligencji rosyjskiej na przełomie XIX $i$ XX wieku, „Przegląd Rusycystyczny” nr 4 (144), s. 37-50. 
Krycka-Michnowska I., 2014, W poszukiwaniu Boga. O odrodzeniu religijnym i „nowym Kościele" w diarystyce Zinaidy Gippius, [w:] Doświadczenie świata w literaturach słowiańskich epoki pre-, modernizmu i post-modernizmu, red. D. Szymonik, R. Mnich, Siedlce - Banská Bystrica, s. 9-19.

Pachmuss T., 1972, Intellect and Ideas in Action. Selected Correspondance of Zinaida Hippius, München.

Skarga B., 1982, Czas i trwanie. Studia o Bergsonie, Warszawa.

Walicki A., 2005, Zarys myśli rosyjskiej. Od oświecenia do renesansu religijno-filozoficznego, Kraków.

Белый А., 1990, Начало века, подгот. текста и коммент. А.В. Лаврова, Москва.

Волкогонова О., Религиозньй анархизм Д. Мережковского, [online], http://lib. philosophical.ru/volk/merez.html [11.09.2015].

Воронцова И.В., 2010, Основополагающие черты христианского модернизма (конеи XIX - начало XX в.), „Вопросы философии”, s. 51-61.

Гиппиус 3.Н., 2003, Без мира, [w:] Тејże, Собрание сочинений, t. 7. Мь и они. Литературный дневник. Публичистика 1899-1916 г2., Москва, s. $140-149$.

Гиппиус 3.Н., 2002, О любви, [w:] Тејże, Мечты и кошмар.Неизвестная проза 1920-1925 годов, Санкт-Петербург, s. 433-459.

Гиппиус 3.Н., 1990, [О „Союзе Непримиримости”], [w:] Т. Пахмусс, Из архивов Зинаидь Николаевны Гиппиус. Ранние годы эмиграчии, „Записки Русской академической группы в США” t. 23, s. 217-222.

Гиппиус 3.Н., 2005, Собрание сочинений, t. 9. Дневники 1919-1941. Из публииистики 1907-1917 ге. Воспоминания современников, Москва.

Злобин В., 1970, Тяжёлая душа, Вашингтон.

Мережковский Д., 1914, Последний святой, [w:] Теgоż, Полное собрание сочинений, t. 13, Москва, s. 98-157.

Мережковский Д.С., 1932, Иисус Неизвестный, Белград.

Мережковский Д.С., 2000, Л. Толстой и Достоевский, изд. подг. Е.А. Андрущенко, Москва.

Пахмусс Т., 2002, Зинаида Гиппиус. Hуратіа двадиатого века, Frankfurt a. Main.

Ходасевич В., 2008, О форме и содержании, [w:] 3.Н. Гиппиус: pro et contra. Личность и творчество Зинаиды Гиппиус в оченке современников и исследователей. Антология, сост., вступ. ст., коммент. А.Н. Николюкина, Санкт-Петербург, s. 636-646. 


\section{CHURCH AND CHRISTIANITY SEEN BY ZINAIDA GIPPIUS}

\section{S U M M A R Y}

The topic of this paper are the religious-philosophical views of Zinaida Gippius expressed in the diary The Choice? Analysis of the diary proves that on the emigration almost at the end of her life Gippius remained faithful to the idea of a great revival of Christianity and its own mission, and especially - the concept of "new ecumenical Church". The diary presents the writer as a critic of "historical Churches" and a promoter of the idea of spiritual rebirth of humanity, which strive to the development of Christianity, especially the dogmas of the Church. The diary presents Gippius as a religious modernist who sees in Christianity a religion of freedom and creativity, and not of authority and tradition. 